NOTE

\title{
Hyperparasitism of trichodinid ciliates on monogenean gill flukes of two marine fish
}

\author{
A. Colorni* ${ }^{*}$ A. Diamant \\ Israel Oceanographic and Limnological Research, National Center for Mariculture, PO Box 1212, Eilat 88112, Israel
}

\begin{abstract}
Two unusual cases of hyperparasitism of trichodinid ciliates on monogenean gill flukes are described from southern Israel (Red Sea). The first case occurred in cultured European sea bass Dicentrarchus labrax infected by Diplectanum aequans, while the second was observed in a feral devil firefish Pterois miles infected by Haliotrema sp. In both cases, the trichodinids heavily coinfested the host fish gills. The flukes were completely coated by the ciliates, which gave them a cobblestone appearance, but no damage to their tegument was apparent. Both cases are most likely a result of accidental hyperparasitism, brought about by perturbed environmental conditions.
\end{abstract}

KEY WORDS: Diplectanum $\cdot$ Haliotrema $\cdot$ Hyperparasitism $\cdot$ Marine fish $\cdot$ Monogenea $\cdot$ Trichodina

Trichodinid protozoans and monogenean flatworms are cosmopolitan aquatic parasites, common on gills and skin of fish in both the freshwater and marine environments. Trichodinids are peritrich ciliates (order Mobilina, family Trichodinidae) that glide on the surface of the fish. They normally feed on bacteria and mucus and are often considered as ectocommensal nuisances rather than true parasites. However, weakening of the host's resistance may encourage their proliferation. Their repeated adherence and suction cause epithelial hyperplasia and hypertrophy in the host. On debilitated individuals, trichodinids are more aggressive, and cell debris and erythrocytes are often found in their food vacuoles (Lom 1995, Noga 1996). Transmission is direct, from fish to fish. Within 8 to $10 \mathrm{~h}$ of the host's death, trichodinids leave the host but, depending on the temperature, may survive for several days in the water (Davis 1961).

Monogeneans are ectoparasitic platyhelminths that feed on the superficial layers of fish skin and gills. Most species of Monogenea have a narrow host range and are restricted to a single species, genus, or family (Rhode 1982, Noga 1996). Proliferation of both tricho- dinids and monogeneans is generally an indication of poor water quality, a stressed, debilitated fish host, or both (Noga 1996). Concurrent infections of trichodinid ciliates and monogenean flukes (e.g. Gyrodactylus, Microcotyle, Lamellodiscus) are not uncommon in cultured fish, where they may act with synergistic deleterious effects (Noble 1963, McVicar \& MacKenzie 1977, Cruz E Silva et al. 1997).

The present report describes 2 unusual cases of hyperparasitism of trichodinid ciliates on monogenean flukes. The first case was observed in March 2001 in a $100 \mathrm{~m}^{3}$ concrete pond holding approximately 30000 European sea bass Dicentrarchus labrax of about $200 \mathrm{~g}$, whose gills were found to be heavily infected by a trichodinid and moderately infected by Diplectanum aequans. Water temperature in the pond was $22 \pm 1^{\circ} \mathrm{C}$ and salinity $40 \%$. The fish had a history of light, chronic Mycobacterium marinum infections and were also infected with Streptococcus iniae, a gram-positive bacterium that produced septicemia with lethal consequences for some $40 \%$ of the stock. The streptococcosis was treated by 2 consecutive antibiotic treatments of Baytril 10\% (enrofloxacin) given orally for 
$10 \mathrm{~d}$ through medicated feed, 2 and 3 mo before, respectively, but the infection was not eradicated. As some antibiotics are known to have an immunosuppressive effect on fish (van Muiswinkel et al. 1985, Karunasagar et al. 1996, Colorni et al. 1998), the treatments may have indirectly triggered proliferation of both the monogenean worms and the trichodinid ciliates on the gills.

Fresh mounts were examined and photographed using standard and differential interference contrast (Nomarski) light microscopy. Klein's dry silver impregnation method was used to stain the trichodinids (Lom \& Dyková 1992). Infected fish gills and worms were fixed in $10 \%$ buffered neutral formalin and embedded in paraffin blocks according to standard procedures (Sheehan \& Hrapchak 1980). Sections of $6 \mu \mathrm{m}$ were stained with hematoxylin-eosin.

The ciliate-infested flukes had a cobblestone-like appearance (Figs. 1 to 4 ). The worms were observed to actively jerk their bodies, vigorously stretching and contracting. Although such movements are typical, their frequency and intensity appeared greater than normal. No lesions or damage to the flukes' tegument structure were apparent histologically.

A second case, remarkably similar to the first, was observed in March 2001 in 1 individual devil firefish (lionfish) Pterois miles, collected in the shallow waters of Eilat's North Beach (water temperature: $22^{\circ} \mathrm{C}$; salinity $40 \%$ ). In this case as well, trichodinid ciliates were found to entirely coat individuals of the dactylogyridean Haliotrema sp. that were co-infesting the fish's gills.

In the Red Sea, at least 2 genera, Tripartiella and Trichodina, have been reported on skin and gills of cultured sea bream Diplodus sargus and Sparus aurata, European sea bass Dicentrarchus labrax and grey mullets (Paperna 1983, 1984), while additional species (Trichodina cf. rectuncinata and $T$. domerguei ssp. domerguei, respectively), were reported from the gills and anal region of wild Siganus spp. (Diamant 1985). According to their morphological features (Figs. 5 to 7), the trichodinids in the present investigation were identified as belonging to the genus Trichodina, and are possibly undescribed species. Partial sequence of the presently observed organisms' 18S rRNA was carried out (André-Denis G. Wright, CSIRO, Wembley, Australia, unpubl. data), but comparison with other trichodinids at the molecular level was not possible, since only Trichodina nobilis sequence has so far been deposited in GenBank.

Reports on hyperparasitic infections of fish monogenea, in particular from the wild, are scarce. Østbø \& Bakke (2003) observed isolated individuals of Ichthyobodo necator (a flagellate previously known as Costia necatrix) on Gyrodactylus salaris Malmberg, infesting Atlantic salmon fished in a Norwegian river. Aguilar et al. (2004) described a myxosporidian, Myxidium
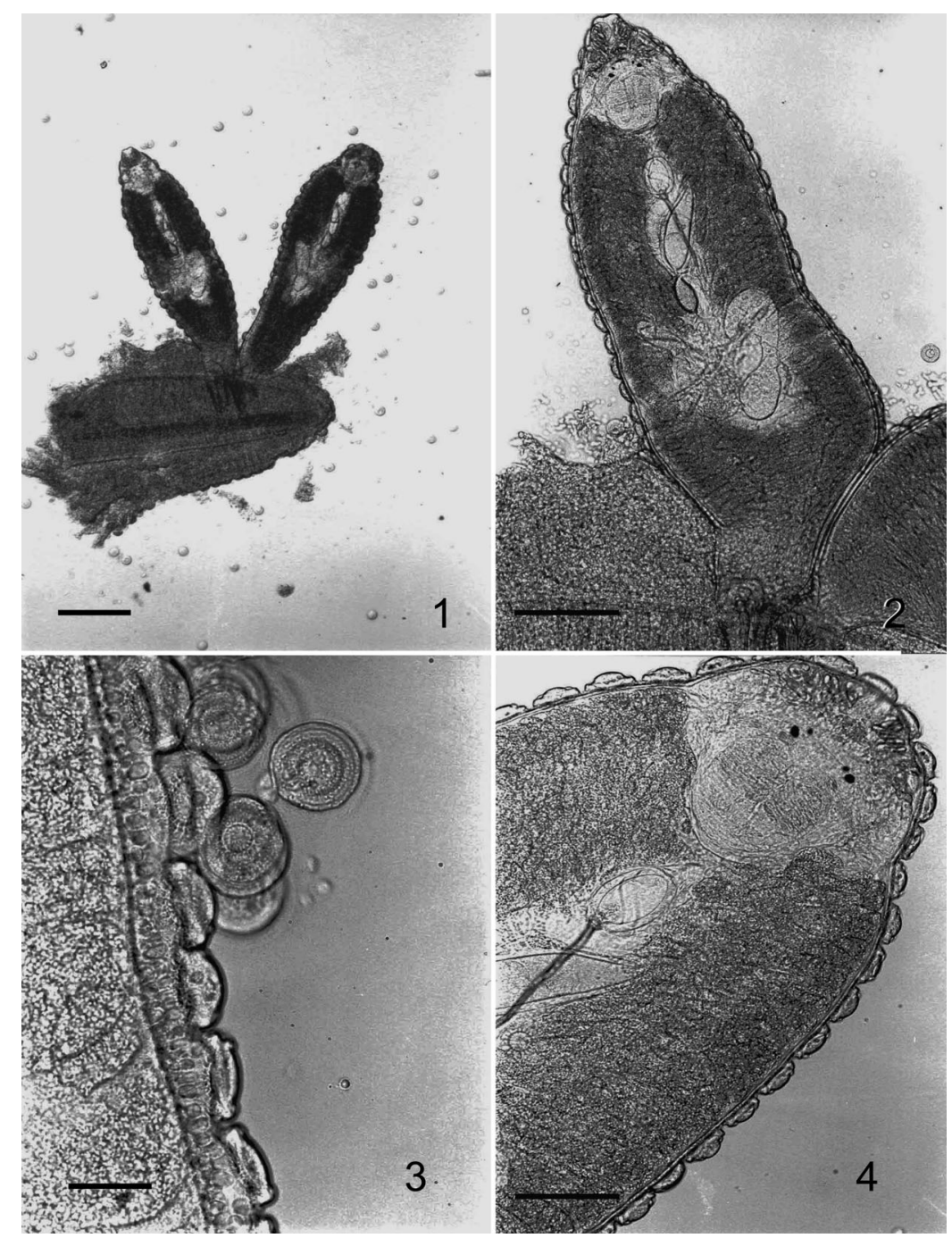

Figs. 1 to 4. Diplectanum aequans. Fig. 1. Two individuals of D. aequans attached to a gill fragment of Dicentrarchus labrax, hyperparasitized with Trichodina sp. Scale bar $=400 \mu \mathrm{m}$. Fig. 2. Hyperparasitized individual of $D$. aequans. Scale bar $=200 \mu \mathrm{m}$. Fig. 3 . High power view of a section of $D$. aequans tegument and Trichodina sp. Scale bar $=50 \mu \mathrm{m}$. Fig. 4. Anterior region of $D$. aequans, displaying the monogenean's tegument studded with numerous cells of Trichodina sp. Scale bar $=100 \mu \mathrm{m}$ 

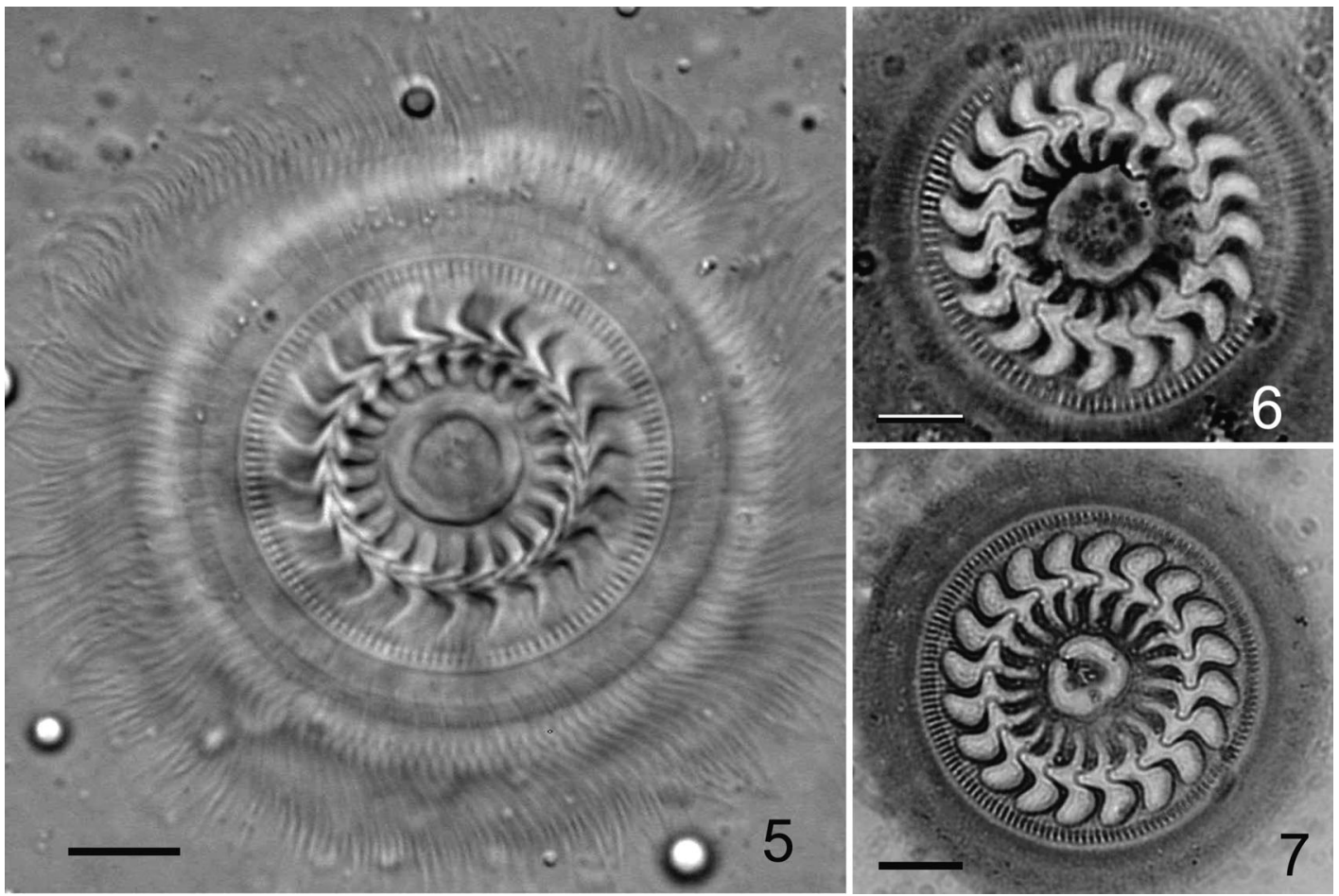

Figs. 5 to 7. Trichodina sp. Fig. 5. Live specimen of Trichodina sp. from Pterois miles (Nomarski differential interference contrast). Scale bar $=10 \mu \mathrm{m}$. Fig. 6. Trichodina sp. from the gills of $P$. miles (Klein's dry silver impregnation method). Scale bar $=10 \mu \mathrm{m}$. Fig. 7. Trichodina sp. from the gills of Dicentrarchus labrax (Klein's dry silver impregnation method). Scale bar $=10 \mu \mathrm{m}$

giardi, hyperparasitizing Pseudodactylogyrus bini, a common gill monogenean of European eel from a river in northwest Spain. Other episodes developed in conditions of intensive aquaculture and involved a microsporidian (Cable \& Tinsley 1992), a dinoflagellate (Colorni 1994), and an unidentified fungus (Mennie et al. 2000). Under perturbed environmental conditions, specificity between fish hosts and their parasitic fauna often breaks down (Rohde 1982, Thoney \& Hargis 1991), and the potential aggressiveness of a parasite towards an unusual host is expressed (Colorni 1994). Whether there was any detrimental impact on the primary parasite on the piscine host in these cases is unknown. Although presently an isolated and apparently rare phenomenon, the occurrence of a hyperparasitic infection observed in wild Pterois miles may be linked to the increasing anthropogenic impact and deteriorating environmental conditions of the northern Gulf of Eilat.

Acknowledgements. We gratefully acknowledge the assistance of Dr. L. A. Chisholm, Dept. of Microbiology and Parasitology, University of Queensland, Brisbane, Australia, for her assistance in the identification of the monogeneans. This work was carried out at the Green-Keiser Fish Health Center, IOLR-NCM, Eilat, with the support of the Yad Hanadiv Fund and the Israel Ministry of National Infrastructures.

\section{LITERATURE CITED}

Aguilar A, Aragort W, Álvarez MF, Leiro JM, Sanmartín M (2004) Hyperparasitism by Myxidium giardi Cépède 1906 (Myxozoa: Myxosporea) in Pseudodactylogyrus bini (Kikuchi, 1929) Gussev, 1965 (Monogenea: Dactylogyridae), a parasite of the European eel Anguilla anguilla L. Bull Eur Assoc Fish Pathol 24:287-292

Cable J, Tinsley RC (1992) Microsporidean hyperparasites and bacteria associated with Pseudodiplorchis americanus (Monogenea: Ploystomatidae). Can J Zool 70:523-529

Colorni A (1994) Hyperparasitism of Amyloodinium ocellatum (Dinoflagellida: Oodinidae) on Neobenedenia melleni (Monogenea: Capsalidae). Dis Aquat Org 19:157-159

Colorni A, Avtalion R, Knibb W, Berger E, Colorni B, Timan B (1998) Histopathology of sea bass Dicentrarchus labrax experimentally infected with Mycobacterium marinum and treated with Streptomycin and garlic (Allium sativum) extract. Aquaculture 160:1-17

Cruz E Silva MP, Freitas MS, Orge ML (1997) Co-infection by monogenetic trematodes of the genus Microcotyle V. Beneden \& Hesse 1863, Lamellodiscus ignoratus Palombi, 1943, the protozoan Trichodina sp. Ehrenberg, 1838 and the presence of epitheliocystis, Vibrio alginolyticus and $V$. vulnificus in cultured seabream (Sparus aurata L.) in Portugal. Bull Eur Assoc Fish Pathol 17:40-42

Davis HS (1961) Culture and diseases of game fishes, 3rd edn. University of California Press, Berkeley, CA

Diamant A (1985) Biology of the parasites of Siganus spp. (Teleosti: Siganidae) from the Northern Red Sea and Eastern Mediterranean coasts of Israel. PhD thesis, Hebrew University of Jerusalem (in Hebrew, English summary) 
Karunasagar I, Kumar Otta S, Ali A, Karunasagar I (1996) Immunization with bacterial antigens: infections with motile aeromonads. International Symposyum on Fish Vaccinology, June 5-7 1996, Oslo, Norway. Book of Abstracts, International Association of Biological Standardization, Oslo, p 23

Lom J (1995) Trichodinidae and other ciliates (Phylum Ciliophora). In: PTK Woo (ed) Fish diseases and disorders, Vol 1. Protozoan and Metazoan infections. CABI Publishing, Oxon

Lom J, Dyková I (1992) Protozoan parasites of fish. Developments in Aquaculture and Fisheries Science, Vol 26. Elsevier, Amsterdam

McVicar AH, MacKenzie K (1977) Effects of different systems of monoculture on marine fish parasites. In: Cherret JM, Sagar GR (eds) Origin of pest, disease and weed problems. Blackwell, Oxford, p 163-182

Mennie DAR, Collins C, Bruno DW (2000) Colonization of Gyrodactylus derjavini (Monogenea: Gyrodactylidae) by fungal-like hyphae. Bull Eur Assoc Fish Pathol 20:215-216

Noble ER (1963) The relation between Trichodina and metazoan parasites on gills of fish. In: Ludvik J, Lom J, Vávra J (eds) Progress in protozoology. Publishing House of the Czeckoslovak Academy of Sciences, Prague, p 521-523

Editorial responsibility: Wolfgang Körting,

Hannover, Germany
Noga EJ (1996) Fish diseases: diagnosis and treatment. Mosby, St. Louis, MO

Østbø M, Bakke TA (2003) Observations of hyperparasitism on Gyrodactylus salaris Malmberg (Monogenea) infecting Atlantic salmon (Salmo salar). Bull Scand Soc Parasitol 12-13:52-53

Paperna I (1983) Review of diseases of cultured warm-water marine fish (1983). Rapp P-V Réun Cons Int Explor Mer 182:44-48

Paperna I (1984) Review of diseases affecting cultured Sparus aurata and Dicentrarchus labrax. In: Barnabé G, Billard R (eds) L'Aquaculture du Bar et des Sparidés. INRA Publ, Paris, p 465-482

Rohde K (1982) Ecology of marine parasites. University of Queensland Press, St Lucia, Queensland, p 50-51

Sheehan DC, Hrapchak BB (1980) Theory and practice of histotechnology, 2nd edn. The CV Mosby Co, St. Louis, MO

Thoney DA, Hargis WJ Jr (1991) Monogenea (Platyhelminthes) as hazards for fish in confinement. Annu Rev Fish Dis 1:133-153

van Muiswinkel WB, Anderson DP, Lamers CHJ, Egberts E, van Loon JJA, Ijssel JP (1985) Fish immunology and fish health. In: Manning MJ, Tatner MF (eds) Fish immunology. Academic Press, London, p 1-8

Submitted: October 25, 2004; Accepted: February 3, 2005 Proofs received from author(s): June 10, 2005 